\title{
Designing and Building of 3D Adventure Game "Tetuko: Childhood of Ghatotkacha" Using Kinect
}

\author{
Achmad Basuki, Jauari Akhmad NH, Jabbar Nendra Putra \\ Creative Industry Research Center \\ Politeknik Elektronika Negeri Surabaya \\ Kampus PENS, Jl. Raya ITS, Sukolilo, Surabaya \\ E-mail: \{basuki,jauari\}@pens.ac.id
}

\begin{abstract}
Nowadays, the young people are not interested in the local culture as a "wayang" puppet. This condition threatens the extinction of some of the local culture that should be a mainstay of the industry entering an era of creative industries. On the other hand, theyare more interested in playing computer games as changing of people's lifestyles. It becomes our basic idea to produce a game as a creative product. The genre of this game is fighting-adventure. This game depictures a story of fighting between the baby Tetuko and giant Kala Pracona. The game uses Kinect and 3D platform technology to attract more players to feel their adventures. With Kinect technology, the player can control the character with his gesture. Thus, this game will increase the awareness of young people about the culture of Wayang.
\end{abstract}

Keywords: 3D game, kinect,adventure, local culture, creative industry.

\section{INTRODUCTION}

The "Wayang"puppet is a local culture that grows from generation to generation as part of Indonesian society. Puppet is a culture that consists of art, music and performances. Because of the two reasons above, the puppet can be one of the promising products in the creative industries in line with what is expressed by Marie Elka Pangestu [1].

In the story of Wayang, there is a famous figure. He is Ghatotkacha or Gatotkaca in Indonesian Language. Many people are familiar with this figure because he is strong and he can fly to the sky. Many young people do not know the story of Ghatotkacha's childhood. We conducted a small survey to find out how much the younger generations know Ghatotkacha figures. Our respondents were 20 students as a representative of young people on campus and the school. We asked about Tetuko, the childhood name of Ghatotkacha. It turned out that 19 of 20 respondents did not know this name. This survey suggested that the culture of the puppet is not attractive to young people. It is our concern to try to make a product with Wayang background. 
On the other hand, young children play computer games as the nowadays lifestyle. That's why the idea to include local cultural content in the game becomes an interesting research issue. Puput Windi [2] revealed that the RPG (Role Playing Game) games make players understand the story and the message conveyed in a game. RPG games could be a good choice to introduce the story of Wayang. Ayu Dyah Pramitasari [3] revealed that the classification of the game corresponding to the level of education would be a good approach to insert a value message. Mohammad Luthfi Folhalit [4] showed the 3D model of puppets with ARToolkit. The Augmented Reality hada huge potential in promoting the attaction of Wayang Kulitas one of the traditional art. Zainal [5] indicated that the level of one's knowledge about a culture may improve if he or she can get a chance to experience about that culture. So, the game with player experience is can be a promising way of preserving a culture.

Based on some of the review earlier, we propose to build a fightingadventuregame with 3D environment and the adventure story of Tetuko. This game has tittle "Tetuko: the childhood of Ghatotkacha". It contains an adventure story and fighting. With this genre, players feel the adventure Tetuko with his battles and plays according to the story. Finally, the player will get to know the story of Tetuko as the uniqueness of the story of Wayang. The young people will know the culture of Wayang as local culture [5].

This game uses the Kinect technology to control the character. Kinect technology is working on gesture recognition. Players control the character to perform movements. Kinect has affordances to create enjoyable, interesting interaction types, to boost player motivation, and to promote content via its multimedia and multi-sensory capacity[6].In this game there are some basic movements to fight as hitting, kicking, jumping and defending. It makes the player feels a special sensation when plays this game.

\section{RELATED WORKS}

The educational history game is a kind of educational game that picked up the story in the history of the plot. This game generally will reconstruct and simulate historical story in the form of games so the user as if the actors were invited to witness even history. In this way the history of the material can be more easily absorbed by the user because it gives the impression that more than just reading books.

Galang W [7] proposed a board-game to lift folklore. In this game, the player can feel a social experience that is not found in many digital games. The key of this game is how the player experience to know the folklore.The game story has content about the story of the island of Java. The genre of this game is memory-game.

Fadilah Fahrul Hardiansyah [8] proposed JTME multiplayer game via Bluetooth to introduce Karapan Sapi. The multiplayer game has an advantage in competitiveness between players. This game is an adventure game. Players play the avatar and get a pair of cows to be included in every game. The area 
represents the game with 4 citiesof Madura such as Bangkalan, Sampang, Pamekasan, and Sumenep. To follow the race in town, players need to collect information from people who are in the city. With this game the player will know about the culture behind the story of Karapan Sapi.

Windi Puput [2] proposes a Role Playing Game (RPG) to introduce several kingdoms in Indonesian history as shown in Figure 1. Target players are children. RPG genre makes players understand the storyline automatically while playing. This game requires the player character to play in accordance with the storyline. It makes this game is more successful in introducing the history of the kingdom because of the involvement of the players in the story.

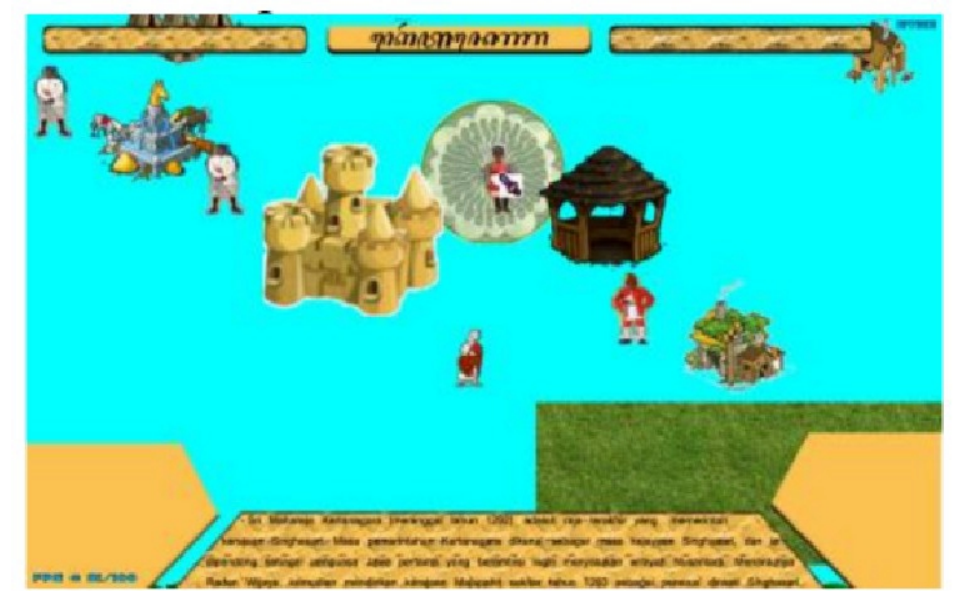

Figure 1. RPG game of history of some kingdom on Indonesia

Dyah Ayu Pramitasari [3] proposed a multiplayer game of learning and the introduction of Indonesian culture for elementary school children grades 3-6 as shown in Figure 2. This game offered a model approach the game in accordance with the level of education. This game trained the child's ability to master the Indonesian regions with wealth in it. Players can decide several options in resolving all game. The advantage of this game is the graphic model with cultural details.

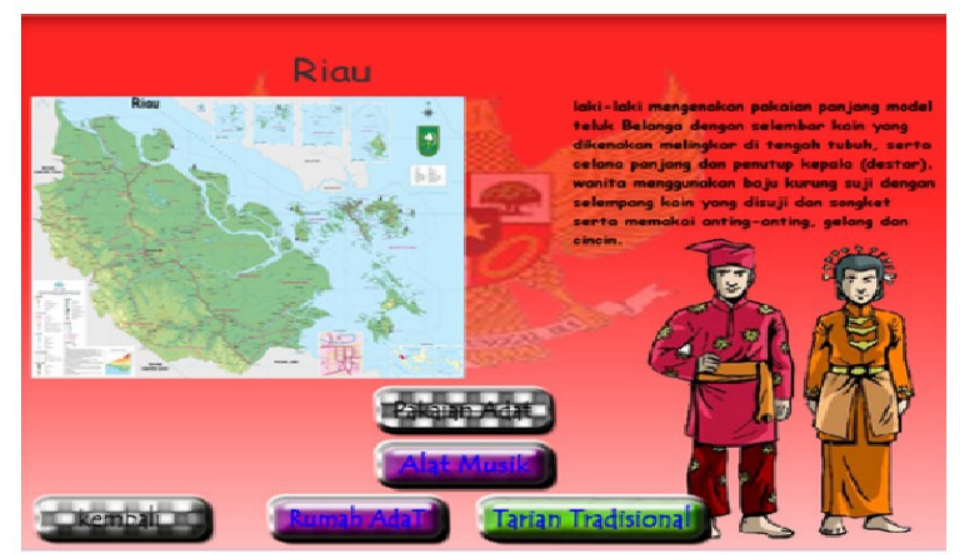

Figure 2. Interface ofcultural choices for playing 


\section{ORIGINALITY}

Game "Tetuko's War" is a fighting-adventure game that tells the adventures and battles Tetuko, the childhood name of Ghatotkacha. This game uses the Kinect technology, so that the player can control the character Tetuko with gesture recognition. Thus the player really feel become Tetuko and his fights. Some movements adapted to the storyline in the story of Tetuko. Players can punch, kick and defend as Tetuko abilities.

This game is not only an alternative to introducing local cultural contents, but also provides an alternative user interface with attractive gesture recognition. This is a new trend that utilized several gaming companies to produce interactive and attractive games.

\section{SYSTEM DESIGN}

The system of game development is shown in Figure 3. Games created using the Unity game engine, with Blender as a modeling engine, and ZDK Zigfu for the configuration of the character control. For general work process of the gameplay, the user must first perform a calibration of Kinect. The Kinect motion sensor which captures the user's body earlier, will be mapping it into rigging the character in gameplay that has been made.
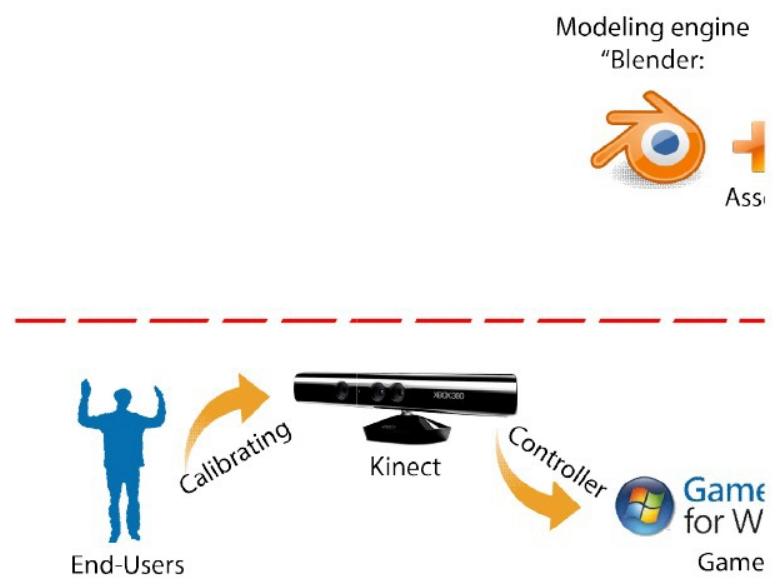

Figure 3. Game development

This game is a fighting-adventure game.There are two important points to make this game:

1. Adventure: the characters will interact with other characters to produce a story that can be understood by the player.At this stage, we build the characters and environmentsadapted on storyline of Tetuko.

2. Battle: Game uses gesture recognition to recognize and adjust to the movement of the player character movement based on the results of the calibration. Players can issue a motion offense and defense to defeat his enemies. 
Tetuko's movement starts from the start point to the end point specified in the map. A player can not determine the route itself. The map created in the form of terrain. In any terrain, there are some areas that have a Collider. Collider will call a certain function when passing through the region Tetuko character. Thus, the Collider is what will determine the route of a journey as shown in Figure 4. Here is the Collider in question as shown in Figure 5.

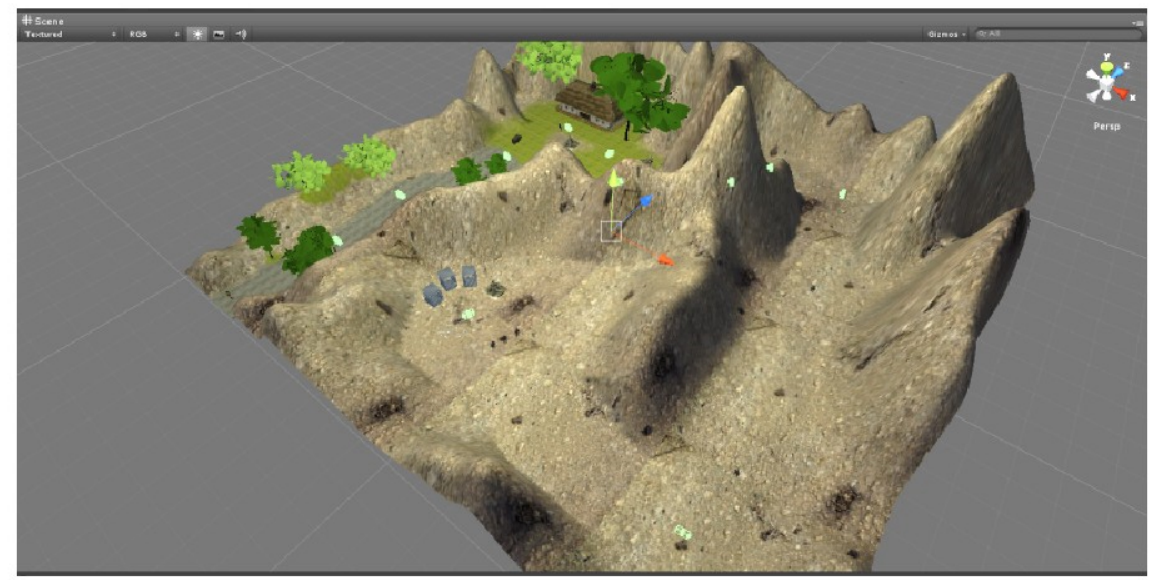

Figure 4. The entire map of journey

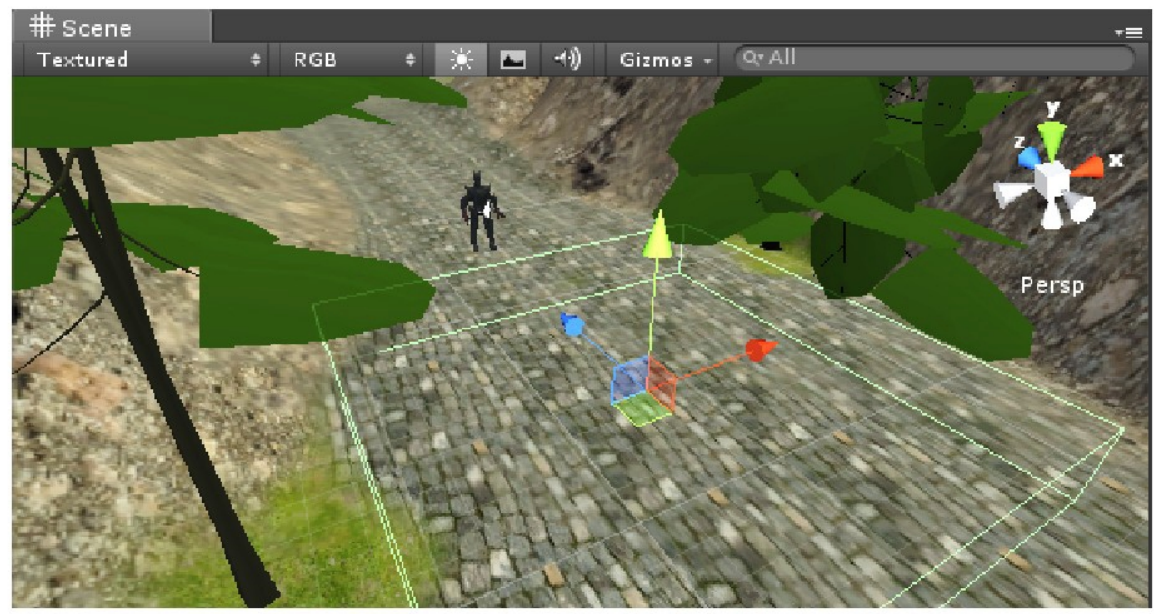

Figure 5. Collider when detect the enemy

The initial process of user-interaction of this game is the calibrationprocess as shown in Figure 6. The calibration process must be carried out prior to play. The distance between the player and the Kinect determine the success of the calibration process. In the calibration process the player to run some motion in the following order:

1. Systems detect the player (user detection).

2. Systems perform to detect the pose player.

3. The pose calibration system detects players.

4. Pose successful calibration.

5. Systems begin to detect the player's movements (user tracking). 


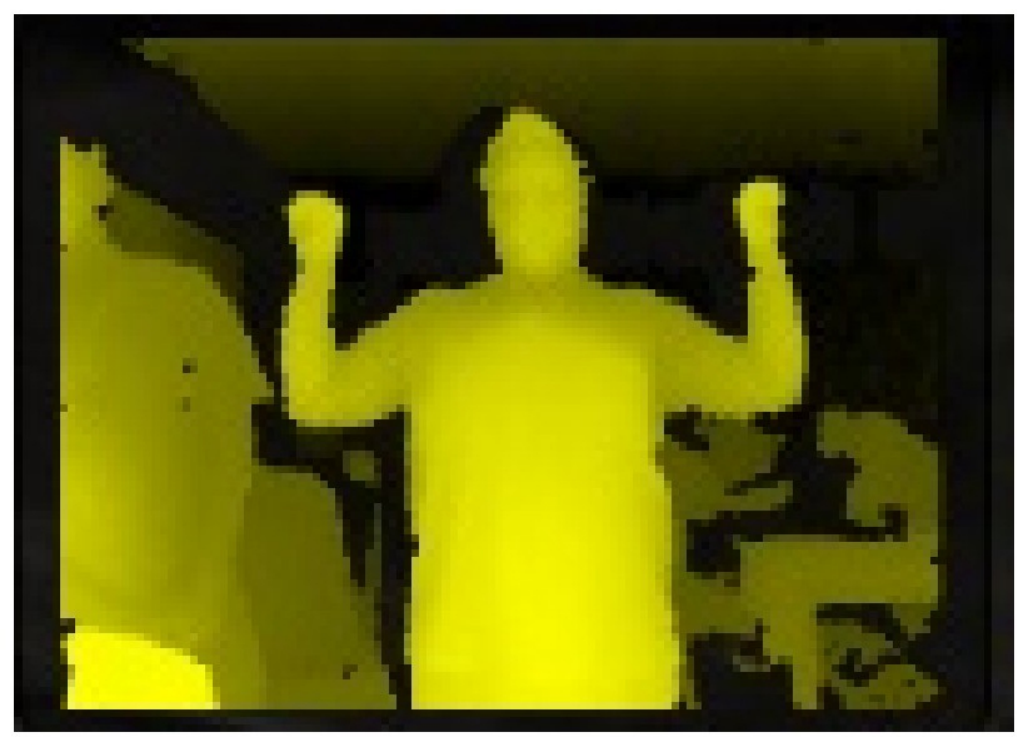

Figure 6. Calibrating

There are two basic movements in the game, namely blocking and attacking. Blocking is done by moving the left hand. Attacking is done by moving the right hand.

1. Blocking: The part that should be exposed colliding first Tetuko is the left hand part, be exposed to new parts of the other. When exposed to enemy attack Tetuko left hand, automatically visible effects of particles. It shows that the character successfully blocking enemy attacks as shown in Figure 7 .

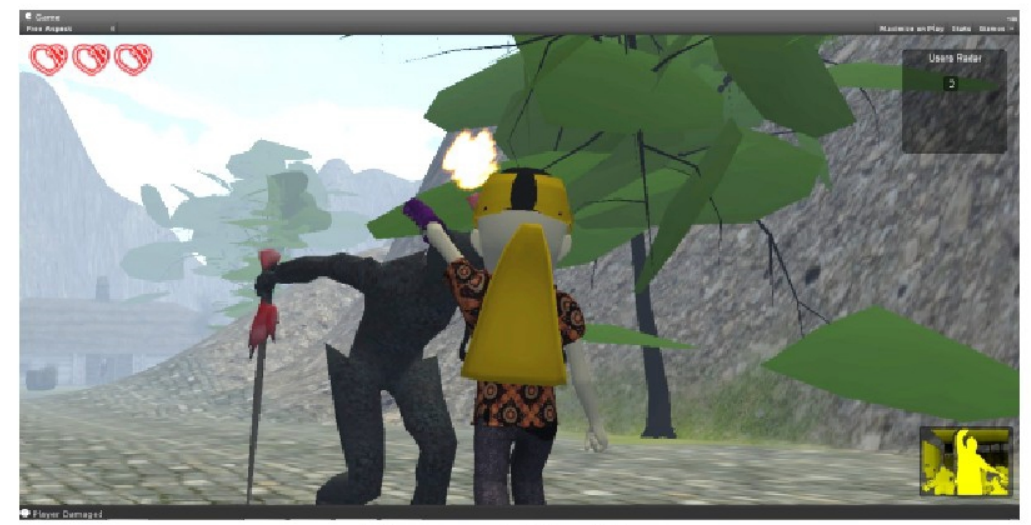

Figure 7. Blocking

2. Attacking: Doing attacking into the enemy, need a clear target. When the right-hand limb of the enemy character, will be seen the effects of fireexplosion particles as shown in Figure 8. It shows that the character of successfully attacking the body toward the enemy. 


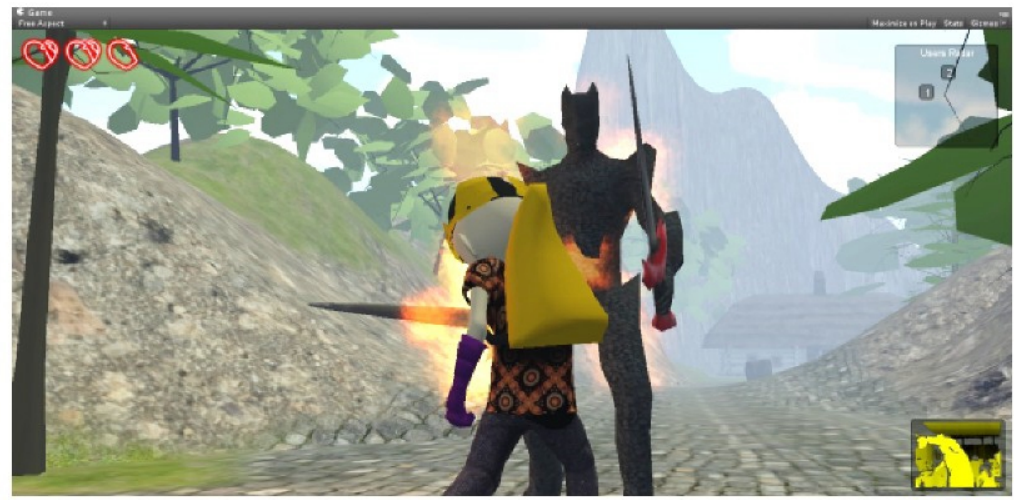

Figure 8. Attacking

\section{EXPERIMENT AND ANALYSIS}

This experiment test all systems in this game. This game works with maximum performance when has the following specifications:

1) Intel(R) Core(TM) i3-238M CPU @ 2.30GHz (4 CPUs), 2.3GHz

2) Memory 2048MB RAM

3) Windows 32 Bit

4) Kinect for Windows

\subsection{Experiment on Calibration Process}

The experiment result is shown in Table 1. It gives the results of the calibration column succeed/fail, whereas the results column will be filled with their effects on the results of the calibration of the character.

Table 1. Kinect's performance depend on disctance between player and kinect

\begin{tabular}{|c|c|c|c|}
\hline$\#$ & Distance (m) & Status & Additional Description \\
\hline 1 & 0.8 & Fail & No movement \\
\hline 2 & 1.0 & Fail & No movement \\
\hline 3 & 1.2 & Success & Character sways irregularly \\
\hline 4 & 1.4 & Success & Character sways irregularly \\
\hline 5 & 1.6 & Success & Character sways irregularly \\
\hline 6 & 1.8 & Success & Hand difficult to move \\
\hline 7 & 2.0 & Success & Hand difficult to move \\
\hline 8 & 2.2 & Success & Ok \\
\hline 9 & 2.4 & Success & Ok \\
\hline 10 & 2.6 & Success & Ok \\
\hline 11 & 2.8 & Success & Hand difficult to move \\
\hline 12 & 3.0 & Success & Hand difficult to move \\
\hline 13 & 3.2 & Success & No movement \\
\hline 14 & 3.4 & Success & No movement \\
\hline 15 & 3.6 & Fail & Fail \\
\hline 16 & 3.8 & & \\
\hline
\end{tabular}

The ideal distance between the player and Kinect sensor in order to capture the motion of the user's body is along the $1.2-3.4 \mathrm{~m}$. Outside of that, 
the Kinect motion sensor can not read the user's body. Meanwhile, at a distance of $1.2-3.4 \mathrm{~m}$ itself produces the mapping sensors to different characters also. The distance is too far or too close from the Kinect, Kinect can not be made properly recognize the gesture.

\subsection{User's Opinion}

In this experiment, we perform the test with 10 people aged between 18-21 years old tester to give an opinion about this game. Tester unlimited game play, then we conduct direct interviews form of easyto control, the story, the quality of graphics and technology implementation. Interview results can be seen in Table 2 .

Table 2. Interview results

\begin{tabular}{|c|c|c|c|c|}
\hline$\#$ & Easy to control & $\begin{array}{c}\text { Understanding } \\
\text { of story }\end{array}$ & $\begin{array}{c}\text { Graphic } \\
\text { Quality }\end{array}$ & $\begin{array}{c}\text { Implementation } \\
\text { of Technology }\end{array}$ \\
\hline 1 & Hard & Easy & Good & Interested \\
\hline 2 & Hard & Easy & Good & Ordinary \\
\hline 3 & Hard & Easy & Good & Ordinary \\
\hline 4 & Hard & Normal & Good & Interested \\
\hline 5 & Hard & Easy & Good & Interested \\
\hline 6 & Middle & Easy & Good & Interested \\
\hline 7 & Hard & Normal & Good & Interested \\
\hline 8 & Hard & Easy & Good & Ordinary \\
\hline 9 & Middle & Easy & Good & Interested \\
\hline 10 & Hard & Difficult & Good & Ordinary \\
\hline
\end{tabular}

Based on interview data, 8 of 10 agree that this game is still hard to control properly. They stated that it is not easy to move according to the movement of the character in the story. But 9 out of 10 agree that this game managed to convey the message that there is a moral to the story. The moral of the story is a way of Tetuko. They become familiar figure Tetuko as one of the characters in Wayang culture. They agree that the quality of the graphics in this game is incredible. Lastly, they stated that the idea of the author to create a game with the Kinect technology can be quite interesting because the technology is still relatively new.

\section{CONCLUSION}

Based on the experiment, we conclude that:

1) Kinect on figthing-adventure game is a new way to play game.

2) The ideal distance for optimal gesture sensor from the player and Kinect is $1.2-3.4 \mathrm{~m}$.

3) The Kinect makes the game becomes more difficult to control but still interesting. 


\section{REFERENCES}

[1] Marie Elka Pangestu, Pengembangan Indutri Kreatif Menuju Visi Ekonomi Kreatif Indonesia 2025, Deperindag 2011.

[2] Puput Windi S, Design of the RPG Game for History of Indonesia's Kingdom with Java Language Learning for Kids and Teens, Final Project, Politeknik Elektronika Negeri Surabaya, 2010.

[3] Ayu Dyah Pramitasari, Multiplayer Game for Learning and Knowing the Indonesian Culture for 5-6th Elementary School, Final Project, Politeknik Elektronika Negeri Surabaya, 2010.

[4] Mohamad Lutfi Dolhalit, Mohd Zulkhairul Hafiz Mat Jun, Ahmad Naim Hanapi and Farah Nadia Azman, The Development of Shadow Play Wayang Kulit using Augmented Reality,International Journal of Interactive Digital Media, Vol. 1(2).

[5] Zainal A. Hasibuan, Yugo K.Isal, Baginda Anggun N.C., Mubarik Ahmad, and Nungki Selviandro, Preservation of Cultural Heritage and Natural History through Game Based Learning, International Journal of Machine Learning and Computing, Vol. 1, No. 5, December 2011.

[6] Hui-mei Justina Hsu, The Potential of Kinect in Education, International Journal of Information and Education Technology, Vol. 1, No. 5, December 2011.

[7] Galang W., Perancangan Board-game Adaptasi Cerita Rakyat sebagai Media Edukasi untuk Siswa Kelas 3 Sekolah Dasar, Final Project, Desain Komunikasi Visual, Institut Seni Indonesia Yogyakarta, 2013.

[8] Fadiliah Fahrul Hardiansyah, Karapan Sapi J2ME Multiplayer Game via Blueetooth, Final Project, Politeknik Elektronika Negeri Surabaya, 2011. 